\title{
MATHEMATICAL MODELING OF OREGONATOR WITH A DIFFUSION TYPE COMMUNICATION
}

L. A. Prokudina, South Ural State University, Chelyabinsk, Russian Federation, prokudina-la@mail.ru

We presented a mathematical model of the Belousov-Zhabotinsky reaction for FieldNoyes mechanism, which is called oregonator, taking into account the diffusion of components. A range of stoichiometric coefficient changes, which corresponds to a stationary state oregonator, is found. We study a diffusion instability and two types of unstable modes, as well as the points of oregonator bifurcation.

Keywords: Field-Noyes model,oregonator, diffusion instability, bifurcation point.

\section{Introduction}

The problem of the origin and development of the ordered structures is very important during the study of open systems, which are able to a metabolism, a change of energy and information $[1-7]$. One deal with the process of an emergence of structures and their development during a study of hydrodynamic, chemical, biochemical, biological, environmental and other non-equilibrium dissipative media [8-12]. In particular, the concentration structures are observed in two-dimensional reactor, where autocatalytic chemical reactions flow $[8,13,14]$. A theory of a formation of structures in molecular systems started with the work of A. Turing [15], E. Schrodinger [16], R. Glansdorff [1], B. Belousov [18], A. Jabotinsky [17, 19]. Chemical reactions give many examples of the formation of dissipative (spatial, temporal and spatio-temporal) structures. One of the first studied reactions of such type is the Belousov reaction [18]. Further studies of oscillatory chemical reactions are associated with the works of Jabotinsky [17, 19] and the emergence of the concept of "Belousov - Zhabotinsky reaction" (abbreviated as BZ). BZ reaction mechanism was developed by R.J. Field, E. Koros and R.M. Noyes [20 - 21] and formed the basis of experimental and theoretical studies of the bromat chemical oscillators. An ability of the components to diffuse is taken into account in the study of physical-chemical, biochemical, ecological systems. An existence of spatially inhomogeneous structures in nonlinear reactant systems with diffusion was first proved by A.M. Turing in 1952 [15]. Spatial structures in space of autocatalytic reaction were observed by the authors of works $[13-14]$. Accounting of a diffusion in the mechanism of these reactions extends the possibilities of mathematical modeling of real physical and chemical processes.

\section{A mathematical model of oregonator}

Mathematical models of autocatalytic reactions with diffusion and the results of their researches are widely used in the study of nonlinear phenomena and effects in biochemical, ecological systems, as for mathematically similar ones. Mathematical modeling of the concentration fluctuations systems was started with the work of A.J. Lotka [22 - 24]. A model known in ecology as "prey-predator" became very popular. In experimental studies, Belousov-Zhabotinsky reaction is popular [19]. A bromide bromomalonic acidferroin (BMF) system is one of the most successful to study the spatial structures. There 
are several mathematical models of the BZ reaction, but the most famous one is the Field-Noyes version, known as Oregonator [20 - 21]:

$$
\begin{aligned}
& A+Y \stackrel{K 1}{\longrightarrow} X, \\
& X+Y \stackrel{K_{2}}{\longrightarrow} P, \\
& B+X \stackrel{K 3}{\longrightarrow} 2 X+Z \\
& 2 X \stackrel{K_{4}}{\longrightarrow} Q, \\
& Z \stackrel{K_{5}}{\longrightarrow} f Y,
\end{aligned}
$$

where $\mathrm{X}$ is bromide acid $\mathrm{HBrO}_{2}, \mathrm{Y}$ is bromide $\mathrm{Br}^{-}, \mathrm{Z}$ is Cerium IV,

$\mathrm{A}=\mathrm{B}$ is bromate ion $\mathrm{BrO}_{3}^{-}, \mathrm{P}=\mathrm{Q}$ is a concentration of products, $f$ is a stoichiometric rate, $k_{i},(i=\overline{1,5})$ are reaction rate constants.

A system of kinetic equations by neglecting of the reverse reactions

$$
\begin{aligned}
& \frac{\partial X}{\partial t}=k_{1} A Y-k_{2} X Y+k_{3} B X-2 k_{4} X^{2} \\
& \frac{\partial Y}{\partial t}=-k_{1} A Y-k_{2} X Y+f k_{5} Z \\
& \frac{\partial Z}{\partial t}=k_{3} B X-k_{5} Z
\end{aligned}
$$

corresponds to the five-step model (1).

Kinetic equations (2) based on a diffusion of components can be written as:

$$
\begin{aligned}
& \frac{\partial X}{\partial t}=k_{1} A Y-k_{2} X Y+k_{3} B X-2 k_{4} X^{2}+D_{X} \frac{\partial^{2} X}{\partial \xi^{2}}, \\
& \frac{\partial Y}{\partial t}=-k_{1} A Y-k_{2} X Y+f k_{5} Z+D_{Y} \frac{\partial^{2} Y}{\partial \xi^{2}}, \\
& \frac{\partial Z}{\partial t}=k_{3} B X-k_{5} Z+D_{Z} \frac{\partial^{2} Z}{\partial \xi^{2}},
\end{aligned}
$$

where $t$ is time, $\xi$ is spatial coordinate, $D_{X}, D_{Y}, D_{Z}$ are coefficients of a diffusion of components.

\section{Steady state of the system}

From (2) we write the stationary model

$$
\begin{gathered}
k_{1} A Y_{0}-k_{2} X_{0} Y_{0}+k_{3} B X_{0}-2 k_{4} X_{0}^{2}=0, \\
-k_{1} A Y_{0}-k_{2} X_{0} Y_{0}+f k_{5} Z_{0}=0 \\
k_{3} B X_{0}-k_{5} Z_{0}=0
\end{gathered}
$$

and find a stationary solution $X_{0}, Y_{0}, Z_{0}$ of the system (4):

$$
X_{0}=\frac{1}{2}\left(\frac{k_{3} B(1-f)}{2 k_{4}}-\frac{k_{1} A}{k_{2}}\right)+\left[\frac{1}{4}\left(\frac{k_{3} B(1-f)}{2 k_{4}}-\frac{k_{1} A}{k_{2}}\right)^{2}+\frac{k_{1} k_{3} A B(1+f)}{2 k_{2} k_{4}}\right]^{1 / 2},
$$




$$
\begin{gathered}
Y_{0}=\frac{k_{3} B(1+f)}{2 k_{2}}-\frac{k_{4}}{k_{2}} X_{0}, \\
Z_{0}=\frac{k_{3} B}{k_{5}} X_{0} .
\end{gathered}
$$

For input parameters [25]: $A=B=6 \cdot 10^{-2}, k_{1}=8 \cdot 10^{9}, k_{2}=2 \cdot 10^{9}, k_{3}=2.1$, $k_{4}=4 \cdot 10^{7}, k_{5}=10^{-4}$ a range of variation of the stoichiometric coefficient is defined and positive stationary solutions $X_{0}, Y_{0}, Z_{0}$ having physical meaning are found and presented in table 1.

Table 1

\begin{tabular}{|l|l|l|l|}
\multicolumn{4}{|c|}{ Stationary solutions for different values of $f$} \\
\hline$f$ & $X_{0}, 10^{-8}$ & $Y_{0}, 10^{-17}$ & $Z_{0}, 10^{-15}$ \\
\hline 0.15 & 0.1811 & 0.0071 & 0.2282 \\
0.25 & 0.1969 & 0.0129 & 0.2481 \\
0.35 & 0.2126 & 0.0195 & 0.2679 \\
0.45 & 0.2284 & 0.0270 & 0.2878 \\
0.55 & 0.2441 & 0.0352 & 0.3076 \\
0.65 & 0.2599 & 0.0443 & 0.3274 \\
0.75 & 0.2756 & 0.0543 & 0.3473 \\
0.85 & 0.2914 & 0.0650 & 0.3671 \\
0.95 & 0.3071 & 0.0766 & 0.3870 \\
1.05 & 0.3229 & 0.0890 & 0.4068 \\
1.15 & 0.3386 & 0.1022 & 0.4267 \\
1.25 & 0.3544 & 0.1163 & 0.4465 \\
1.35 & 0.3701 & 0.1312 & 0.4664 \\
\hline
\end{tabular}

An increasing of a concentration of the components is observed with an increasing of the value of the stoichiometric coefficient in the system.

\section{Diffusion instability}

Stationary solutions $X_{0}, Y_{0}, Z_{0}$ determine the equilibrium states of the system. Assume $X=X_{0}+x, Y=Y_{0}+y, Z=Z_{0}+z$, i.e. deviate from equilibrium, and write the system (3) in perturbations $x, y, z[26]$ :

$$
\begin{aligned}
& \frac{\partial x}{\partial t}=a_{1} x+a_{2} y+a_{3} x y+a_{4} x^{2}+D_{x} \frac{\partial^{2} x}{\partial \xi^{2}} \\
& \frac{\partial y}{\partial t}=b_{1} y+b_{2} x+b_{3} z+b_{4} x y+D_{y} \frac{\partial^{2} y}{\partial \xi^{2}} \\
& \frac{\partial z}{\partial t}=c_{1} x+c_{2} z+D_{z} \frac{\partial^{2} z}{\partial \xi^{2}} .
\end{aligned}
$$

The coefficients of equations of system (6) have the form: 


$$
\begin{aligned}
& a_{1}=-k_{2} Y_{0}+k_{3} B-4 k_{4} X_{0} ; \\
& a_{2}=k_{1} A-k_{2} X_{0} ; a_{3}=-k_{2} ; a_{4}=-2 k_{4} ; \\
& b_{1}=-k_{1} A-k_{2} X_{0} ; b_{2}=-k_{2} Y_{0} ; b_{3}=f k_{5} ; \\
& b_{4}=-k_{2} ; c_{1}=k_{3} B ; c_{2}=-k_{5} .
\end{aligned}
$$

Consider a stability of the steady state with respect to perturbations $x_{j}(\xi, t) \approx \exp (k \xi-\omega t)$ and obtain the dispersion equation

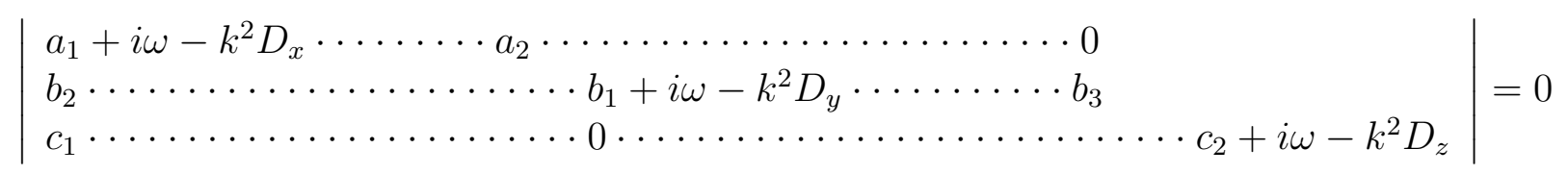

or correspondingly

$$
\omega^{3}-i p_{1} \omega^{2}+p_{2} \omega-i p_{3}=0,
$$

where $\omega=\omega_{r}+i \omega_{i}, \omega_{r}$ is a frequency, $\omega_{i}$ is a velocity of the perturbation growth.

The coefficients of the dispersion equation (7) have the form:

$$
\begin{aligned}
& p_{1}=a_{1}+b_{1}+c_{2}-k^{2}\left(D_{x}+D_{y}+D_{z}\right), \\
& p_{2}=\left(a_{1}+b_{1}-k^{2}\left(D_{x}+D_{y}\right)\right)\left(c_{2}-k^{2} D_{z}\right)+\left(a_{1}-k^{2} D_{x}\right)\left(b_{1}-k^{2} D_{y}\right)-a_{2} b_{2}, \\
& p_{3}=\left(a_{1}-k^{2} D_{x}\right)\left(b_{1}-k^{2} D_{y}\right)\left(c_{2}-k^{2} D_{z}\right)+a_{2} b_{3} c_{1}-a_{2} b_{2}\left(c_{2}-k^{2} D_{z}\right) .
\end{aligned}
$$

The results of computational experiments as part of the equation (7) by varying of diffusion coefficients showed a diffusion instability of oregonator for a range of stoichiometric coefficient $f \in(0 ; 1.4)$ with the values of the wave number $k \geq 0$ (Fig. 1 ). The criterion of oregonator instability is a condition $\omega_{i} \geq 0$.

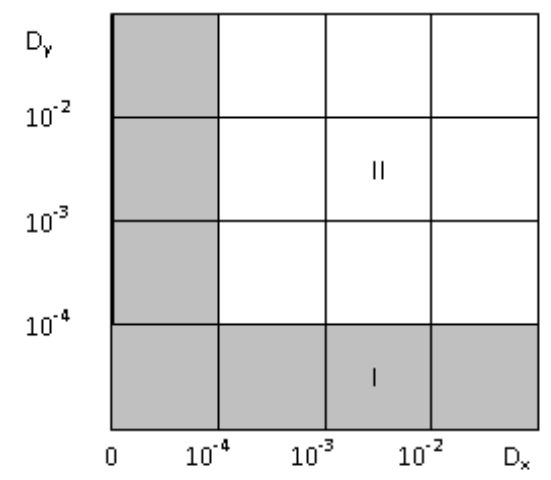

Fig. 1. Areas of oregonator instability for $f=0,7$ : I - area of a stabilizing effect of diffusion; II area of a destabilizing effect of diffusion

In areas of oregonator instability a diffusion has both stabilizing effect (Fig. 1, area I), and the destabilizing one (Fig. 1, area II). In the area of stabilizing effect of diffusion in oregonator a decrease of the velocity of perturbation growth is marked (Fig. 2, curve 1). An area of a destabilizing effect of diffusion is characterized by an increasing of a velocity of perturbation growth (Fig. 2, curve 2).

Different vibrational modes are observed for different wave numbers in oregonator (Table 2). 


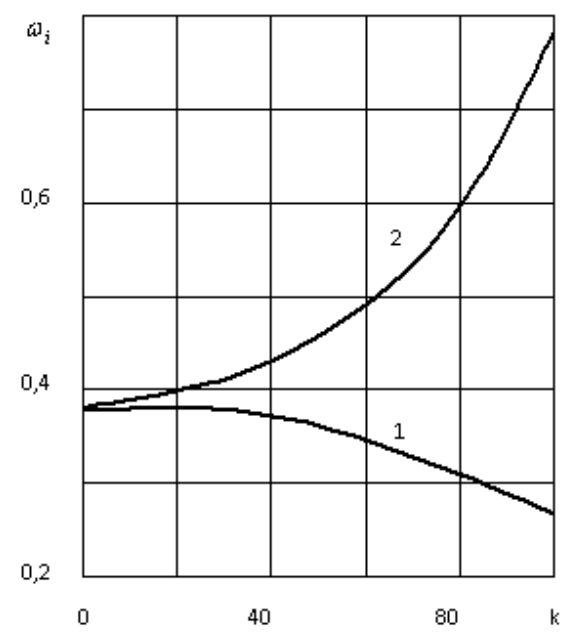

Fig. 2. The dependence of a velocity of perturbation growth on the wave number: $1-D_{X}=0,0001, D_{Y}=0,002 ; 2-D_{X}=0,008, D_{Y}=0,016$

Table 2

The values of frequency and velocity of perturbation growth for $f=0.55$

\begin{tabular}{|l|l|l|}
\hline$k$ & $\omega_{r}, 10^{-8}$ & $\omega_{i}$ \\
\hline 1 & -0.0056 & 0.2910 \\
3 & 0 & 0.3594 \\
5 & 0.0777 & 0.4962 \\
7 & 0 & 0.7015 \\
9 & 0.0444 & 0.9752 \\
11 & 0.0888 & 1.3173 \\
13 & -0.0888 & 1.7278 \\
15 & -0.3553 & 2.2068 \\
17 & -0.3997 & 2.7542 \\
19 & -0.0444 & 3.3700 \\
\hline
\end{tabular}

The velocity of perturbation growth in Oregonator is determined by a value of the bifurcation parameter $f$. An instability of the system increases, when parameter $f$ increases (Fig. 3).

A pair of numbers $(k, f)$, corresponding to the new state of the system, is defined as a point of bifurcation of the system. In accordance with the physical sense of the process two unstable modes should be allocated:

1. $\mathrm{i}>0, \mathrm{r}=0$;

2. $\mathrm{i}>0, \mathrm{r}>0$,

where the first mode is called a mode of stability change, and the second one - a mode of oscillatory instability.

A type of instability in oregonator changes with increasing of value $f$. For example, for values $f \in(0 ; 0,5103)$ a mode of the change of stability is observed, and for values $f \in[0,5103 ; 0,9914]$ a oscillatory instability mode is observed. A mode of the change of stability is characterized by velocity of perturbation growth, which is higher then for oscillatory instability mode. 


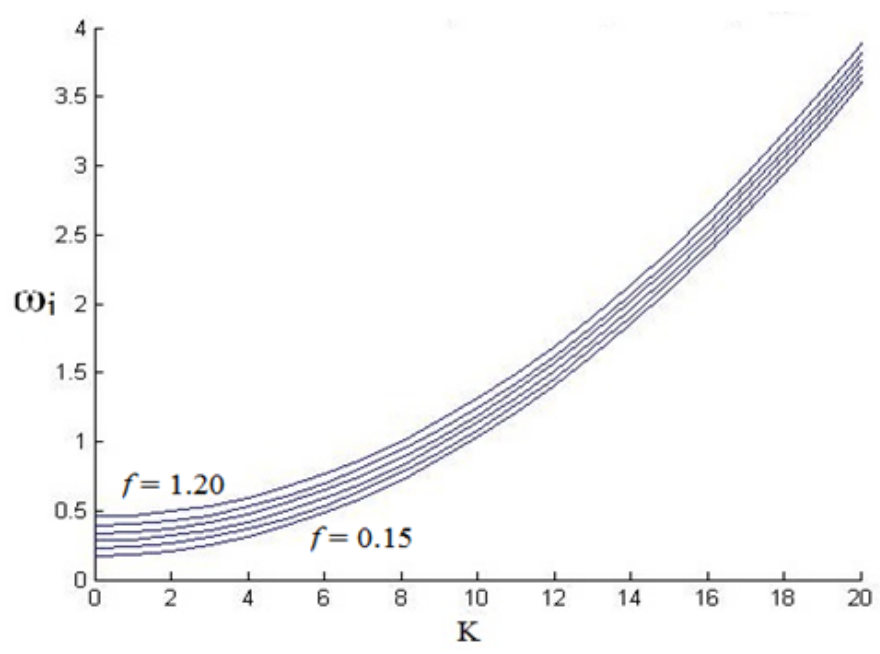

Fig. 3. Dependence of velocity of perturbation growth on the wave number for different values $f$

\section{References}

1. Glansdorff P., Prigogine I. Thermodynamic Theory of Structure, Stability and Fluctuations. Moscow, Mir Publ., 1973. (in Russian)

2. Nicolis G., Prigogine I. Self-organization in Nonequilibrium Systems. Moscow, Mir Publ., 1979. (in Russian)

3. Nicolis G., Prigogine I. Exploring of Complexity. Moscow, Mir Publ., 1990.(in Russian)

4. Prigogine I. From Being to Becoming. Moscow, Nauka Publ., 1985. (in Russian)

5. Haken H. Synergetics. Moscow, Mir Publ., 1980. (in Russian)

6. Haken H. Synergetics. The Hierarchy of Instabilities in Self-organizing Systems and Devices. Moscow, Mir Publ., 1985. (in Russian)

7. Ebeling W. Emergence of Structures in Irreversible Processes. Moscow, Mir Publ., 1979. (in Russian)

8. Herschkowitz-Kaufman M. Structures Dissipatives dans une Reaction Chimique Onhomogene. Comp. Rend. Acad. Sci., 1970. vol. 270, no. 12, pp. 1049-1052.

9. Kuramoto Y. Chemical Oscillations, Waves, and Turbulence. Berlin, Heidelberg, Springer, 1984. doi: 10.1007/978-3-642-69689-3

10. Jabotinsky A.M. Concentration Autooscillations. Moscow, Nauka Publ., 1974. (in Russian)

11. Köros E. Oscillatory Processes in Biological and Chemical Systems. Moscow, Nauka Publ., 1978. (in Russian)

12. Field R., Burger M.Vibrations and Traveling Waves in Chemical Systems. Moscow, Mir Publ., 1988. (in Russian) 
13. Busse H.G. A Spatial Periodic Homogeneous Chemical Reaction. J. Phys. Chem, 1969, vol. 73 , no. 3 , p. 750 .

14. Beck M.T., Varadi Z.B. One, Two and Three-Dimensional Spatially Periodic Chemical Reactions. Nature Phys. Sci, 1972, vol. 235, pp. 15-16. doi:10.1038/physci235015a0

15. Turing A.M. The Chemical Basis of Morphogenesis. Philosophical Transactions of the Royal Society of London. Series B, Biological Sciences, 1952, vol. 237, no. 641, pp. 37-72.

16. Schrödinger E. What is Life. Cambridge, Cambridge Press, 1944.

17. Jabotinsky A.M. Periodic Oxidation Reaction in the Liquid Phase. Dokl. Akad. Nauk SSSR, 1964, vol. 157, pp. 392-395. (in Russian)

18. Belousov B.P. Batch Reaction and Its Mechanisms. Sb. referatov po radiacionnoj medicine - Coll. Abstracts on Radiation Medicine, 1959, pp. 145-148. (in Russian)

19. Jabotinsky A.M. Periodic Process of Oxidation Malonate in Solution (the Study of the Kinetics of the Belousov Reaction). Biophysics, 1964, vol. 9, pp. 306-311. (in Russian)

20. Field R.J., Köros E., Noyes R.M. Oscillations in Chemical Systems. 2. Thorough Analysis of Temporal Oscillations in the Bromate- Cerium- Malonic Acid System. J. Am. Chem. Soc., 1972, vol. 94, no. 25, pp. 8649-8664.

21. Field R.J., Noyes R.M. Oscillations in Chemical Systems IV. Limit Cycle Behaviour in a Model of a Real Chemical Reaction. J. Chem. Phys., 1974, vol. 60, no. 5, pp. $1877-1884$.

22. Lotka A.J. Contribution to the Theory of Periodic Reactions. Phys. Chem. Soc., 1910, no. 14, pp. 271-274.

23. Lotka A.J. Undamped Oscillations Derived from the Law of Mass Action. J. Am. Chem. Soc., 1920, no. 42, pp. 1595-1599.

24. Lotka A.J. Analytical Note on Certain Rhytmic Relations in Inorganic Systems. Proc. Natl. Acad. Sci. USA, 1920, no. 6, pp. 410-415.

25. Edelson D., Field R.J., Noyes R.M. Mechanistic Details of the Belousov-Zhabotinskii Reaction. Int. J. Chem. Kin, 1975, vol. 7, no. 3, pp. 417-432.

26. Prokudina L.A. Modeling of Instability of Oregonator with Diffusion. Nelineinyi mir Nonlinear World, 2014, vol. 12, no. 1, pp. 042 - 047. (in Russian)

Liudmila A. Prokudina, Doctor of Physico-Mathematical Sciences, Docent, Department of Applied Mathematics, South Ural State University (Chelyabinsk, Russian Federation), prokudina-la@mail.ru

Received June 1, 2016 
УДК $519.87: 577.3+544.1$

DOI: $10.14529 /$ jcem1602006

\title{
МАТЕМАТИЧЕСКОЕ МОДЕЛИРОВАНИЕ СОСТОЯНИЯ ОРЕГОНАТОРА С ДИФФУЗИОННЫМ ТИПОМ СВЯЗИ
}

\section{Л. А. Прокудина}

\begin{abstract}
Представлена математическая модель реакции Белоусова-Жаботинского для механизма Филда-Нойеса, называемая орегонатором, с учетом диффузии компонентов. Найден интервал изменений стехиометрического коэффициента, которому соответствует стационарное состояние орегонатора. Исследована диффузионная неустойчивость, выделены два типа неустойчивых режимов, а также точки бифуркации орегонатора.

Ключевые слова: модель Филда-Нойеса, орегонатор, диффузионная неустойчивость, точки бифуркации.
\end{abstract}

\section{Литература}

1. Гленсдорф, П. Термодинамическая теория структуры, устойчивости и флуктуаций / П. Гленсдорф, И. Пригожин. - М.: Мир, 1973.

2. Николис, Г. Самоорганизация в неравновесных системах / Г. Николис, И. Пригожин. - М.: Мир, 1979.

3. Николис, Г. Познание сложного / Г. Николис, И. Пригожин. - М.: Мир, 1990.

4. Пригожин, И. От существующего к возникающему / И. Пригожин. - М.: Наука, 1985.

5. Хакен, Г. Синергетика / Г. Хакен. - М.: Мир, 1980.

6. Хакен, Г. Синергетика. Иерархия неустойчивостей в самоорганизующихся системах и устройствах / Г. Хакен. - М.: Мир, 1985.

7. Эбелинг, В. Образование структур при необратимых процессах / В. Эбелинг. М.: Мир, 1979.

8. Herschkowitz-Kaufman, M. Structures Dissipatives Dans Une Reaction Chimique Onhomogene / M. Herschkowitz-Kaufman // Comp. Rend. Acad. Sci. - 1970. - V. 270, № 12 . - P. 1049-1052.

9. Kuramoto, Y. Chemical Oscillations, Waves, and Turbulence / Y. Kuramoto. - Berlin, Heidelberg: Springer, 1984.

10. Жаботинский, А.М. Концентрационные автоколебания / А.М. Жаботинский. М.: Наука, 1974.

11. Кёрос, Е. Колебательные процессы в биологических и химических системах Е. Кёрос, М. Орбан. - М.: Наука, 1978.

12. Филд, Р. Колебания и бегущие волны в химических системах / Р. Филд, М. Бургер. - М.: Мир, 1988. 
13. Busse, H.G. A Spatial Periodic Homogeneous Chemical Reaction / H.G. Busse / J. Phys. Chem. - 1969. - V. 73, № 3. - P. 750.

14. Beck, M.T. One, Two and Three-Dimensional Spatially Periodic Chemical Reactions / M.T. Beck, Z.B. Varadi // Nature Phys. Sci. - 1972. - V. 235. - P. 15-16.

15. Turing, A.M. The Chemical Basis of Morphogenesis / A.M. Turing // Philosophical Transactions of the Royal Society of London. Series B, Biological Sciences. - 1952. V. 237, № 641. - P. 37-72.

16. Schrödinger, E. What is Life. / E. Schrodiner. - Cambridge: Cambridge Press, 1944.

17. Жаботинский, А.М. Периодические реакции окисления в жидкой фазе / А.М. Жаботинский // ДАН СССР. - 1964. - Т. 157. - С. 392-395.

18. Белоусов, Б.П. Периодически действующая реакция и ее механизмы / Б.П. Белоусов // Сб. рефератов по радиационной медицине. - 1959. - С. 145-148.

19. Жаботинский, А.М. Периодический процесс окисления малоновой кислоты в растворе (исследование кинетики реакции Белоусова) / А.М. Жаботинский // Биофизика. - 1964. - Вып. 9. - С. 306-311.

20. Field, R.J. Oscillations in Chemical Systems. 2. Thorough Analysis of Temporal Oscillations in the Bromate- Cerium- Malonic Acid System / R.J. Field, E. Köros, R.M. Noyes // J. Am. Chem. Soc. - 1972. - V. 94, № 25. - P. 8649-8664.

21. Field, R.J. Oscillations in Chemical Systems IV. Limit Cycle Behaviour in a Model of a Real Chemical Reaction / R.J. Field, R.M. Noyes // J. Chem. Phys. - 1974. V. 60, № 5. - P. 1877-1884.

22. Lotka, A.J. Contribution to the Theory of Periodic Reactions / A.J. Lotka // Phys. Chem. Soc. - 1910. - № 14. - P. 271-274.

23. Lotka, A.J. Undamped Oscillations Derived from the Law of Mass Action A.J. Lotka // J. Am. Chem. Soc. - 1920. - № 42. - P. 1595-1599.

24. Lotka, A.J. Analytical Note on Certain Rhytmic Relations in Inorganic Systems A.J. Lotka // Proc. Natl. Acad. Sci. USA. - 1920. - № 6. - P. 410-415.

25. Edelson, D. Mechanistic Details of the Belousov-Zhabotinskii Reaction / D. Edelson, R.J. Field, R.M. Noyes // Int.J.Chem.Kin. - 1975. - V. 7, № 3. - P. 417-432.

26. Прокудина, Л.А. Моделирование неустойчивости орегонатора с диффузией Л.А. Прокудина // Нелинейный мир. - 2014. - Т. 12, № 1. - С. 042-047.

Прокудина Людмила Александровна, доктор физико-математических наук, профессор, кафедра прикладной математики, Южно-Уральский государственный университет (2. Челябинск, Российскал Федерация), prokudina-la@mail.ru

Поступила в редакцию 1 июня 2016 г. 